\title{
PWWP2A Gene
}

National Cancer Institute

\section{Source}

National Cancer Institute. PWWP2A Gene. NCI Thesaurus. Code C122890.

This gene may play a role in protein-protein or protein-DNA interactions. 